\title{
Parental knowledge and beliefs on the use of child car restraints in Singapore: a qualitative study
}

Ronald Ming Ren $\underline{T a n}^{1,2}$, MBBS, MRCPCH, Chaoyan Dong ${ }^{3}$, PhD, Germac Qiaoyue $\underline{S h e n}^{1}$, BN, Jasmine Xun Yi Feng ${ }^{1}$, BN, Rupini Piragasam ${ }^{4}$, BSc, Arif Tyebally ${ }^{1,2}$, MRCPCH, MMed, Shu-Ling Chong ${ }^{1,2}$, MRCPCH, MPH

INTRODUCTION Road traffic injuries and fatalities represent a significant public health problem. In Singapore, compliance with appropriate child car restraints (CCRs) is poor. We aimed to understand parental knowledge, beliefs and barriers regarding the use of CCRs.

METHODS In this qualitative study, we conducted five focus group discussions with parents who drive with their children in private cars. Participants were recruited using the KK Women's and Children's Hospital's social media page. Guiding questions were derived by consensus following literature review and adaptation to the Singapore context, exploring parental perceptions of CCR use. Focus group interviews were then transcribed and analysed.

RESULTS 33 participants were recruited, with an age range of 28-46 (mean age 35.5) years. They had a total of 46 children with ages ranging from 2.5 months to 14 years (mean age 4.2 years). Three key themes were identified: parental knowledge regarding CCRs, barriers to CCR use, and suggestions to increase CCR compliance. Barriers to compliance included lack of knowledge, difficult child behaviour and cultural norms. A multipronged approach was proposed to increase CCR use, including educating the public, reinforcing positive behaviour, legal enforcement as a deterrent to non-compliance, increasing CCR installation services, providing CCRs for taxi users and offering financial incentives.

CONCLUSION Non-compliance to CCR use is multidimensional, including multiple potentially modifiable factors. This study could inform ongoing collaborative injury prevention efforts among healthcare professionals, industry partners and the traffic police, using public education and outreach to reduce the burden of road traffic injuries.

Keywords: child car restraint, focus group, injury prevention

\section{INTRODUCTION}

Road traffic injuries represent a significant public health issue..$^{(1-3)}$ Accidental injury is the main cause of paediatric death in the United States, with road traffic accidents being the leading cause of injury. ${ }^{(4)}$ Child car restraints (CCRs) are shown to lower the risk of injury by up to $82 \%$ and risk of death by $28 \%$ compared to seat belts. ${ }^{(5-7)}$ The American Academy of Pediatrics has published evidence-based recommendations for CCRs: rear-facing restraints for infants up to two years of age; forward-facing restraints for children up to four years of age; booster seats for children up to eight years of age; seatbelts for children who outgrow booster seats; and for all children under 13 years of age to travel in the rear seat. ${ }^{(8)}$

In Asia, given the rapid urbanisation accompanied by an increasing number of vehicles, road traffic injury rates have remained stable or increased in recent years. ${ }^{(2,9-11)}$ In Singapore, a highly urbanised Asian country, the Road Traffic Act states that CCR use is mandatory. ${ }^{(12)}$ However, compliance to the use of appropriate CCRs is poor. ${ }^{(13,14)}$ In a retrospective cohort study of 2,468 road traffic injury patients seen in Singapore paediatric emergency departments, $51 \%$ of motor vehicle passengers were unrestrained at the time of the accident. Non-compliance to CCRs is significant even from the infant stage. ${ }^{(13)}$ This contrasts with data from the United States, where non-compliance to CCRs occurs in older age groups. ${ }^{(15)}$ Furthermore, up to $30 \%$ of child passengers under the age of 12 are commonly placed in the front seats in Singapore. ${ }^{(13)}$ This is concerning because the younger the child is, the more significant the injuries sustained are, should the child be involved in a motor vehicle collision. These findings represent an issue of public health importance that needs to be addressed by injury researchers and child road safety advocates.

Investigators worldwide are recognising the importance of parental knowledge and attitudes towards establishing compliance with CCRs. Both qualitative and cross-sectional studies have been carried out across Asia, North and South America, Europe, the Middle East and Africa. ${ }^{(16-27)}$ These studies found that parental non-compliance to the use of CCRs is multifactorial. Several potential reasons were identified, ranging from knowledge deficits on the importance of CCRs in the event of a collision ${ }^{(16-27)}$ to practical barriers, such as facing difficult behaviour when the child refuses to stay in the car restraint ${ }^{(18,21,23-25,27)}$ and the prohibitive cost of the car restraint. ${ }^{(19-20,22,27)}$

The question arises of whether the same factors influence parents' decisions on whether to use child car restraints in Singapore. We aimed to understand the knowledge, beliefs and difficulties experienced by Singapore parents on this issue. We postulated that non-compliance to the use of CCRs is multidimensional, as previously mentioned, and that many of these factors are potentially modifiable. Understanding the root causes would facilitate collaboration with public agencies when

${ }^{1}$ Department of Emergency Medicine, KK Women's and Children's Hospital, ${ }^{2}$ Duke-NUS Medical School, ${ }^{3}$ Department of Education, Sengkang General Hospital, ${ }^{4}$ KK Research Centre, KK Women's and Children's Hospital, Singapore

Correspondence: Dr Ronald Ming Ren Tan, Consultant, Department of Emergency Medicine, KK Women's and Children's Hospital, 100 Bukit Timah Road, Singapore 229899. Ronald.tan.m.r@singhealth.com.sg 
Table I. Composition of focus groups.

\begin{tabular}{|llllll|}
\hline Group no. & No. of participants & Gender & Age range $(\mathbf{y r})$ & No. of children & Age of children \\
\hline 1 & 6 & 4 female, 2 male & $31-41$ & $1-3$ & $3 \mathrm{mth}-11 \mathrm{yr}$ \\
\hline 2 & 7 & 5 female, 2 male & $28-41$ & $1-4$ & $8 \mathrm{mth}-14 \mathrm{yr}$ \\
\hline 3 & 8 & 4 female, 4 male & $29-46$ & $1-4$ & $9 \mathrm{mth}-9 \mathrm{yr}$ \\
\hline 4 & 7 & 6 female, 1 male & $28-42$ & $1-3$ & $2 \mathrm{mth}-10 \mathrm{yr}$ \\
\hline 5 & 5 & 3 female, 2 male & $35-44$ & $1-2$ & $9 \mathrm{mth}-8 \mathrm{yr}$ \\
\hline
\end{tabular}

designing public awareness campaigns, which are critical to advance injury prevention efforts in the long term.

\section{METHODS}

A qualitative research approach, specifically focus group discussion, was used to explore participants' perceptions regarding CCR use. A widely used technique in transportation safety research, focus group discussions allow free discussion among participants on multiple issues to obtain more detailed insights. ${ }^{28,29}$

We conducted five focus group interviews at KK Women's and Children's Hospital (KKH), Singapore. KKH has the largest children's emergency department in Singapore, serving approximately 180,000 patients per year. Upon institutional review board approval (SingHealth IRB reference number 2017/3116), the research team posted the study invitation on the hospital's social media webpage. Only parents who responded to the invitation were contacted by one of the research team members. Parents who owned private cars and who transported their children in their own cars were included. Non-car owners were excluded.

Each focus group discussion lasted approximately one hour. Only the research team and study participants were present during each interview. Prior to the start of the focus group discussion, written consent was obtained from each parent individually, during which they were allowed to clarify any questions about the study. During the focus group discussion, the moderator used a set of predefined questions derived by consensus after literature review and adaptation to the Singapore context, classified according to the following domains: parental knowledge on the significance of road traffic collisions as a leading cause of death among children and young adults; compliance to child car seats; parental knowledge and perception of the appropriate CCR for children of different ages; and safety of front-seat child passengers (Appendix).

The characteristics of the research team, as per the COREQ (consolidated criteria for reporting qualitative research) checklist, ${ }^{(30)}$ were as follows: two of the authors, both female, were the primary focus group interviewers. Dong $\mathrm{C}$ is assistant director of a hospital education department and a medical education researcher with a background in educational technology, and has research interests in qualitative analysis; and Chong SL is a paediatric emergency physician-researcher with an interest in public health and child safety. Participants met the research team at a mutually agreed time and the interviewers gave a brief introduction of the study aims prior to commencing the focus group discussion.
From February to May 2018, we conducted five focus group interviews for a total of 33 participants (11 male, 22 female), with 5-8 parents in each session. Each participant attended only one focus group session. None of the participants withdrew from the study. Preliminary data analysis was carried out after each focus group discussion. By the completion of the fifth interview, the data had reached saturation point, indicating that no further new ideas were likely to arise from additional focus groups. The 33 participants' ages ranged from 28 to 46 (mean 35.5) years. The participants had a total of 46 children with ages ranging from 2.5 months to 14 years (mean 4.2 years). Each participant had 1-4 (mean 1.8) children. The composition of each focus group is shown in Table I.

All interviews were audio recorded and then transcribed. These verbatim transcripts and field notes, taken by research team members, captured information in the participants' own words. Transcripts were made available to the research team but not returned to the participants for comments, as participants were not contacted following the focus group sessions. Themes were derived from identifying recurring words, phrases and ideas throughout the transcripts. Thematic analysis was performed by three researchers who first coded the transcripts independently and then discussed any discrepancies in the analysis. Analysis was performed until additional layering of themes yielded no further information.

\section{RESULTS}

Three key themes were identified: (a) parental knowledge regarding CCRs; (b) barriers to CCR use; and (c) suggestions to increase CCR use. These are presented in table format with supporting representative quotations.

Quotations incorporated five subthemes of parental knowledge regarding CCRs, as summarised in Box 1. Technical knowledge related to car restraints was most frequently cited $(n=33)$, in particular, when to change to the next age-appropriate car restraint $(n=16)$, including transitions both from rear-facing to front-facing car seats, and to booster seats. Among these 16 respondents, 14 were confident of their knowledge in this area and two were unsure. 18 parents commented on their information sources for CCRs, primarily the Internet $(n=10)$, relatives, friends and colleagues, the news media and department store salespersons. Ten parents noted that the car restraint was important to reduce injuries, citing previous accidents or near-misses, or theoretical knowledge of physics. Seven parents articulated familiarity with the use of CCRs being mandated by law in Singapore. 


\section{Box 1. Parental knowledge regarding child car restraints:}

Technical aspects $(\mathbf{n}=\mathbf{3 3})$

-When to transition the child through different stages of car restraints $(n=16)$

- Skills for installation and proper use of the car restraint $(n=6)$

- How to get a reliable car restraint $(n=5)$

- Whether car restraints expire $(n=3)$

- Whether carrying the baby in babywear can substitute for a car restraint $(n=3)$

Information source $(\mathbf{n}=\mathbf{1 8})$

Importance or effectiveness of child car

restraints $(n=10)$

Where to obtain child car restraints $(n=9)$

Legal requirements $(\mathrm{n}=7)$
- "I do not know what is the age limit."

- "I really don't know... I thought I remember it's the weight also."

- "I did a lot of research online, YouTube, reading up."

- "If you touch it, it seems okay, it seems sturdy and then it seems heavy."

- "Not sure if car seats actually have an expiry date."

- "Sometimes when my wife uses the baby carrier, we just think, 'Okay, then just leave the car seat at home."'

- “Google."

- "Word of mouth... cousins, friends who have kids before us."

- "If you gave birth to a child, you raise the kid, so you want to protect the child."

- "Statistics show that it's important for kids."

- "Department store for babies."

- "Carousell. It's secondhand." (Carousell is an online application and shopping platform where secondhand items are sold.)

- "First of all, it's a legal requirement to put the kid in a child seat."

Table II. Comparison of studies exploring parental knowledge and beliefs on CCRs.

\begin{tabular}{|c|c|c|c|c|}
\hline Study & Research method & $\begin{array}{l}\text { Country (locality); per capita } \\
\text { GNI; mandatory status* }\end{array}$ & No. & Main reasons for non-compliance ${ }^{\dagger}$ \\
\hline Present study & $\begin{array}{l}\text { Qualitative focus group, } \\
\text { convenience sampling }\end{array}$ & $\begin{array}{l}\text { Singapore; high-income; } \\
\text { mandated }\end{array}$ & 33 & $\begin{array}{l}\text { Knowledge deficits; child behaviour; cultural } \\
\text { norms (or lack thereof) }\end{array}$ \\
\hline Decina et al ${ }^{(21)}$ & $\begin{array}{l}\text { Qualitative focus group, } \\
\text { purposive sampling }\end{array}$ & $\begin{array}{l}\text { USA ( } 4 \text { cities); high-income; } \\
\text { mandated }\end{array}$ & 72 & $\begin{array}{l}\text { Lack of familiarity with child booster seats; belief that } \\
\text { booster seats do not add safety value; difficulty with } \\
\text { installation; child's difficult behaviour; lack of law } \\
\text { enforcement }\end{array}$ \\
\hline Chen et al ${ }^{(17)}$ & $\begin{array}{l}\text { Qualitative interview, } \\
\text { purposive sampling }\end{array}$ & $\begin{array}{l}\text { China (Shantou); upper middle } \\
\text { income; not mandated }\end{array}$ & 14 & $\begin{array}{l}\text { Lack of publicity and poor safety awareness; } \\
\text { problems with installation and removal; CCR taking } \\
\text { away a seat that an adult passenger could use }\end{array}$ \\
\hline Andijani ${ }^{(25)}$ & $\begin{array}{l}\text { Cross-sectional survey, } \\
\text { convenience sampling }\end{array}$ & $\begin{array}{l}\text { Saudi Arabia (Riyadh); } \\
\text { high-income; mandated }\end{array}$ & 400 & $\begin{array}{l}\text { CCR believed to be unnecessary; no space in car due } \\
\text { to large family; child refusal to stay in car seat }\end{array}$ \\
\hline Ma et $\mathrm{al}^{(23)}$ & $\begin{array}{l}\text { Cross-sectional survey, } \\
\text { convenience sampling }\end{array}$ & $\begin{array}{l}\text { Russia (Lipetskaya Oblast); } \\
\text { high-income; mandated }\end{array}$ & 164 & $\begin{array}{l}\text { Child did not like to sit in car restraint; car restraint } \\
\text { deemed unnecessary }\end{array}$ \\
\hline Yoon and $\mathrm{Kim}^{(20)}$ & $\begin{array}{l}\text { Cross-sectional survey, } \\
\text { convenience sampling }\end{array}$ & $\begin{array}{l}\text { South Korea ( } 5 \text { cities); } \\
\text { high-income; mandated }\end{array}$ & 1,573 & $\begin{array}{l}\text { Multiple children in household; low household } \\
\text { income; perception of no need for CCRs }\end{array}$ \\
\hline $\begin{array}{l}\text { Valent and } \\
\text { Barbone }^{(24)}\end{array}$ & $\begin{array}{l}\text { Cross-sectional survey, } \\
\text { convenience sampling }\end{array}$ & $\begin{array}{l}\text { Italy (northeastern region); } \\
\text { high-income; mandated }\end{array}$ & 1,093 & $\begin{array}{l}\text { Child unable to tolerate being restrained; child only } \\
\text { transported for a short trip; vehicle without seatbelts } \\
\text { on the back seat; child held by an adult passenger }\end{array}$ \\
\hline Noor et al ${ }^{(16)}$ & $\begin{array}{l}\text { Cross-sectional survey, } \\
\text { convenience sampling }\end{array}$ & $\begin{array}{l}\text { Malaysia ( } 2 \text { states); upper } \\
\text { middle income; not mandated }\end{array}$ & 500 & $\begin{array}{l}\text { Contention surrounding the understanding that } \\
\text { CCRs prevent severe injury or death in a crash }\end{array}$ \\
\hline Garcês et al ${ }^{(22)}$ & $\begin{array}{l}\text { Cross-sectional survey, } \\
\text { convenience sampling }\end{array}$ & $\begin{array}{l}\text { Brazil (Sao Luis); upper middle } \\
\text { income; mandated }\end{array}$ & 200 & Did not consider it important; no financial resources \\
\hline $\begin{array}{l}\text { Purc-Stephenson } \\
\text { et al }{ }^{(19)}\end{array}$ & $\begin{array}{l}\text { Cross-sectional survey, } \\
\text { convenience sampling }\end{array}$ & $\begin{array}{l}\text { China (Beijing); upper middle } \\
\text { income; not mandated }\end{array}$ & 843 & $\begin{array}{l}\text { Difficulty finding safety seats; cost; preference to } \\
\text { hold child on lap }\end{array}$ \\
\hline $\begin{array}{l}\text { Sevketoğlu } \\
\text { et } \mathrm{al}^{(26)}\end{array}$ & $\begin{array}{l}\text { Cross-sectional survey, } \\
\text { convenience sampling }\end{array}$ & $\begin{array}{l}\text { Turkey (Istanbul); upper } \\
\text { middle income; not mandated }\end{array}$ & 532 & Did not know what a car safety seat was \\
\hline Ndu et $\mathrm{al}^{(27)}$ & $\begin{array}{l}\text { Cross-sectional survey, } \\
\text { purposive sampling }\end{array}$ & $\begin{array}{l}\text { Nigeria (Enugu state); lower } \\
\text { middle income; mandated }\end{array}$ & 458 & $\begin{array}{l}\text { Child was uncomfortable; restraints not important; } \\
\text { restraints too expensive }\end{array}$ \\
\hline Siddiqui et al $\mathrm{l}^{(18)}$ & $\begin{array}{l}\text { Cross-sectional survey, } \\
\text { convenience sampling }\end{array}$ & $\begin{array}{l}\text { Pakistan (Karachi); lower } \\
\text { middle income; not mandated }\end{array}$ & 212 & $\begin{array}{l}\text { Thought CCRs were unnecessary; unaware of CCRs; } \\
\text { parent had difficulty using; child behaviour }\end{array}$ \\
\hline
\end{tabular}

*Mandated by law at time of study. +Listed in order of frequency. CCR: child car restraint; GNI: gross national income 


\begin{tabular}{|c|c|}
\hline \multicolumn{2}{|c|}{ Box 2. Barriers to child car restraint use and examples of responses: } \\
\hline $\begin{array}{l}\text { Knowledge deficits }(\mathbf{n}=\mathbf{3 1}) \\
\text { - Newborns }(\mathrm{n}=12) \\
\text { - Installation skills }(\mathrm{n}=8) \\
\text { - Doubt regarding importance/effectiveness }(\mathrm{n}=5) \\
\text { - Technical knowledge }(\mathrm{n}=3) \\
\text { - Lack of public education/reliable information } \\
(\mathrm{n}=3)\end{array}$ & $\begin{array}{l}\text { - "I strapped her in a carrier and I didn't put the car seat across because I had heard } \\
\text { about the child not breathing, being strapped." } \\
\text { - "At one month, the car seat looks really big and then the baby looks really tiny." } \\
\text { - "It was really difficult, and we had to read the manual many times and watch } \\
\text { YouTube videos to figure out how to fix it." } \\
\text { - "How do you put (him) in the car seat when he's so fragile?" } \\
\text { - "A lot of focus is on the infants and babies, but the older kids are being neglected, } \\
\text { in a sense, and you can't really find information on what kind of seats they should } \\
\text { use." } \\
\text { - "For a long time, we don't see some kind of education materials." }\end{array}$ \\
\hline $\begin{array}{l}\text { Child behaviour }(n=22) \\
\text { - Crying and refusal to get into or stay in seat }(n=14) \\
\text { - Insisting on mimicking older children and adults } \\
\text { not in car seats }(n=4) \\
\text { - Having to change early from rear-facing to } \\
\text { front-facing due to behaviour }(n=3) \\
\text { - Older children unbuckling themselves }(n=1)\end{array}$ & $\begin{array}{l}\text { - "It was a whole year of crying - every car ride, there was crying." } \\
\text { - "Because he sees the other two older children without car seats, he thinks, 'If they } \\
\text { can do without car seat, so why am I buckled in a 5-point harness?"' } \\
\text { - "We used rear-facing car seat, so until nine months, we tried the front-facing } \\
\text { (car seat), from then on, he didn't scream." } \\
\text { - "He knows how to unbuckle the seat belt." }\end{array}$ \\
\hline $\begin{array}{l}\text { Cultural norms (or lack thereof) }(\mathbf{n}=\mathbf{1 2}) \\
\text { - Societal norm in other high-income countries } \\
(\mathrm{n}=9) \\
\text { - Lack of norms }(n=3)\end{array}$ & $\begin{array}{l}\text { - "In the US (United States), it is very well-enforced and even at the hospital level, you } \\
\text { are not allowed to be discharged unless the baby is checked in with a car seat. But } \\
\text { there are a lot of resources, like someone actually helps them check that the car } \\
\text { seat is appropriate." } \\
\text { - "Quite a common thing in the other countries, the Scandinavian countries; in the } \\
\text { States, it's a must." } \\
\text { - "We know that in other countries, they are very strict about it." } \\
\text {-"I see a lot of children whose parents let them move around (in the car) without seat } \\
\text { belt." }\end{array}$ \\
\hline $\begin{array}{l}\text { Inconvenience }(\mathbf{n}=9) \\
\text { - Lack of space in car }(n=6) \text {; } \\
\text { - Difficulty carrying car seat in public places }(n=2) \\
\text { - Reluctance of taxi drivers }(n=1)\end{array}$ & $\begin{array}{l}\text {-"If I were to put two car seats in the car, I can't take any more passengers." } \\
\text { - "Small cars that cannot accommodate big car seats." } \\
\text {-"Who wants to haul it (car seat) around the shopping centre?" } \\
\text {-"Taxi drivers aren't very friendly about it... they are like, 'Why you take so long?"' }\end{array}$ \\
\hline Cost $(n=8)$ & - "Retail price of car seats here are a lot more expensive than they are in Australia." \\
\hline Injury fallacies $(n=6)$ & $\begin{array}{l}\text { - "People just think that it won't happen to them." } \\
\text { - "I drive very well. I'm a very safe driver." } \\
\text { - "The child seldom sits in the car; it's only during the weekends that we bring her } \\
\text { out, and it's not for long distance." }\end{array}$ \\
\hline Lack of law enforcement $(n=6)$ & - “Car seat regulation is not really enforced." \\
\hline Generational norms $(n=6)$ & $\begin{array}{l}\text { - "We grow up in the kind of era (whereby) we don't even wear seatbelts, let alone car } \\
\text { seats." } \\
\text { - "Grandparents are very fixated on them, that something to do with the spine is bad } \\
\text { in the car seat." }\end{array}$ \\
\hline $\begin{array}{l}\text { Differing standards for cars/taxis }(\mathbf{n}=\mathbf{4}) \\
\text { - Inconsistent standards }(n=2) \\
\text { - Non-car owners reluctant to buy }(n=2)\end{array}$ & $\begin{array}{l}\text { - “Parents who (don't) drive and need (transport)... there's a double standard." } \\
\text { - “They don't travel much in a car and take public transport instead. So they do not } \\
\text { see the need to own a car seat." }\end{array}$ \\
\hline
\end{tabular}

Nine subthemes encompassing various barriers encountered by parents when using CCRs are presented in Box 2. Parents identified a wide spectrum of knowledge gaps $(n=31)$. Child behaviour was frequently identified as the reason for non-compliance $(n=22)$. Inconvenience and the high cost of car restraints were also cited. Injury fallacies included perceptions that accidents would not happen to them, self-assessment of safe driving skills, and short duration or frequency of being in the car. 'Normal practice' was brought up 12 times, highlighting the relative lack of CCR use as the norm in Singapore in contrast to CCR use in other highincome countries such as the United States and Australia. Another common thread mentioned was lack of enforcement. Although CCR use is mandated by law in Singapore, the apparent lack of enforcement resulted in many parents not complying with the use of CCRs. Generational norms were also mentioned. Asian families tend to live in close proximity, with grandparents helping to take care of grandchildren, and many grandparents object to using car restraints due to their bulkiness and inconvenience, or the misperception that car restraints are bad for an infant's spine.

Parents were forthcoming with suggestions to encourage the use of CCRs. Full details are in Box 3. Public education was the most-cited approach $(n=53)$ : parents said information has to be provided by a trustworthy regulatory body; mass media and social media should be used to reach out to the public on the importance of car restraints; antenatal classes and hospitals serve as touch points to engage parents; and, as key stakeholders, 


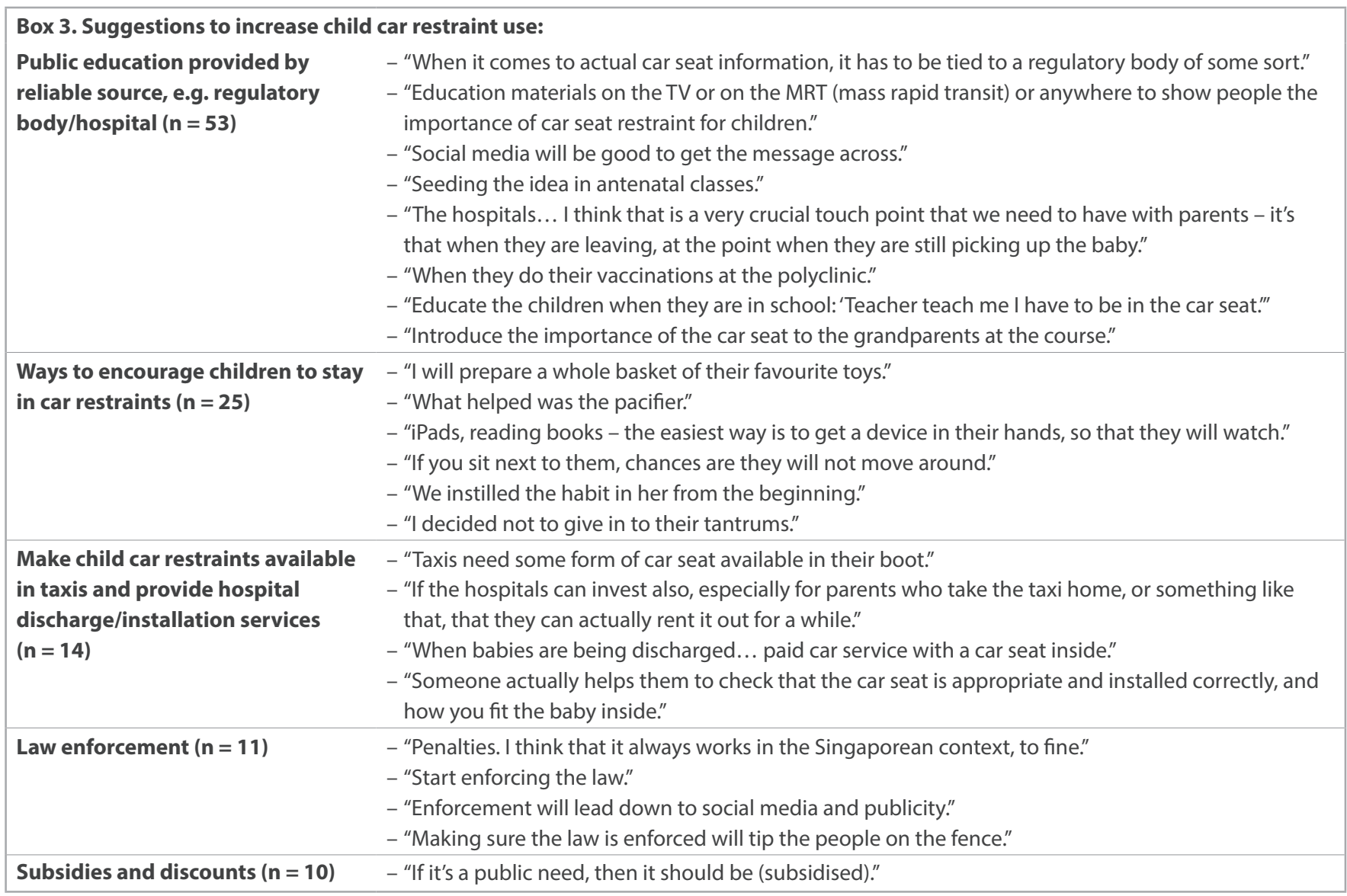

children themselves and grandparents should be educated on the use of CCRs. Other suggestions involved reinforcing positive child behaviour, legal enforcement as a deterrent to non-compliance, increasing car restraint installation services, providing car restraints for taxi users and offering financial incentives from the government.

\section{DISCUSSION}

Previous studies have demonstrated that adherence to best road safety practices in Singapore remains lacking, particularly in the suboptimal use of appropriate CCRs and transporting children under 10 years of age in the front seat. ${ }^{(13,14)}$ This is the first qualitative study in Singapore that uses focus group interviews to address the use of CCRs. By interviewing parents who drive their children in their own cars, we identified knowledge deficits and modifiable factors that can guide future public education efforts on CCR use. During the focus group interviews, technical aspects were discussed, especially selecting age-appropriate car restraints. Parents recognised the importance of CCRs and that their use is mandated by Singapore law. Many parents considered lack of knowledge, difficult child behaviour and a perception of cultural or generational norms as key barriers to the widespread acceptance of CCRs. An encouraging fact was that several, if not all, of the barriers were potentially modifiable factors. To this end, parents suggested a multipronged approach to tackle non-compliance, with an emphasis on reliable public education.

Comparing and contrasting the findings of various qualitative and cross-sectional studies exploring parental knowledge on and attitudes towards CCR use worldwide (Table II) suggested an overlap between parental views in different countries. Regarding perceived barriers or reasons cited for non-compliance, common themes were identified across studies in high-income countries, as classified by per capita gross national income. ${ }^{(31)}$ These mainly centred around lack of parental knowledge (e.g. believing that the CCR is unnecessary) and difficult child behaviour (e.g. refusal to stay in the car restraint). ${ }^{(20,21,23-25)}$ In upper-middle- and lowermiddle-income countries, ${ }^{(31)}$ common themes also included the cost of obtaining a CCR as a barrier, in addition to lack of knowledge and difficult child behaviour. ${ }^{(16-19,22,26,27)}$

Cultural practices in different parts of the world may explain some of the patterns and responses that were seen. In China and Korea, as in Singapore, some parents and grandparents prefer to hold their babies in their arms. ${ }^{(19,20)}$ This was also noted in Italy, where an adult passenger holding the child was a reason for non-compliance. ${ }^{(24)}$ Parents in Singapore and Korea also tend to keep their newborn infant at home for the first 1-2 months of life, except for necessary visits to the clinic for vaccinations, which may explain why parents initially did not purchase CCRs. ${ }^{(20)}$

Translating these findings into actionable plans would require a concerted interdisciplinary effort between healthcare professionals and the wider law enforcement establishment, as well as public education to influence or change the attitudes of the general public. CCRs are required by law in 84 countries worldwide as of 2018. However, only 41 countries base this law on age or height criteria. ${ }^{(3)}$ Furthermore, even if parents do use a 
CCR, levels of correct usage may vary. ${ }^{(19,32)}$ Systematic reviews of intervention programmes to increase CCR use show that while education-only programmes are insufficient, there is evidence for the effectiveness of child safety seat laws, and education paired with incentive, distribution or enforcement programmes. ${ }^{(33,34)}$ As an example of successful implementation, in Greece, maternity hospital-based loan schemes for infant car restraints were found to be cost-effective. ${ }^{(35)}$

Our qualitative research study has the potential to enhance interdisciplinary childhood injury prevention collaboration in Singapore. This not only includes advocacy and outreach, educating the general public and law enforcement officers in conjunction with distribution and/or incentive programmes to lower potential financial barriers (such as subsidised low-cost car restraints), but also further research to study trends of car restraint use following the introduction of any interventions. For instance, we have made available information on age-appropriate CCRs on our hospital website, started introducing education initiatives in antenatal classes, and established platforms for postnatal discharge planning to improve accessibility for newborns leaving the hospital.

We recognise the limitations of our study. The parents interviewed were reached through convenience sampling from those who responded to a social media invitation. Hence, some selection bias is inevitable. In spite of this, the information we obtained is valuable as a source of pilot data to guide further research in this area. This qualitative study allowed us to explore parental knowledge and beliefs, but not specific behaviours or actual compliance to CCRs. It is a crucial first step in understanding the high rate of non-compliance to child car seats, in the Singapore context. Our findings facilitate further collaboration among the healthcare profession, traffic police law enforcers, automobile associations and industry partners to improve child passenger safety.

\section{ACKNOWLEDGEMENT}

This research was supported by the Mitsui Sumitomo Insurance Welfare Foundation Research Grant, Singapore.

\section{SUPPLEMENTARY MATERIAL}

The Appendix is available online at https://doi.org/10.11622/ smedj.2019023.

\section{REFERENCES}

1. Hyder AA, Paichadze N, Toroyan T, Peden MM. Monitoring the decade of action for global road safety 2011-2020: an update. Glob Public Health 2017; 12:1492-505.

2. Wismans J, Skogsmo I, Nilsson-Ehle A, et al. Commentary: status of road safety in Asia. Traffic Inj Prev 2016; 17:217-25.

3. World Health Organization. Global status report on road safety 2018. Available at: https://www.who.int/violence_injury_prevention/road_safety_status/2018/ en/. Accessed December 20, 2018.

4. Centers for Disease Control and Prevention (CDC). Vital signs: unintentional injury deaths among persons aged 0-19 years - United States, 2000-2009. MMWR Morb Mortal Wkly Rep 2012; 61:270-6.

5. Arbogast KB, Durbin DR, Cornejo RA, Kallan MJ, Winston FK. An evaluation of the effectiveness of forward facing child restraint systems. Accid Anal Prev 2004; 36:585-9.

6. Zaloshnja E, Miller TR, Hendrie D. Effectiveness of child safety seats vs safety belts for children aged 2 to 3 years. Arch Pediatr Adolesc Med 2007; 161:65-8.

7. Elliott MR, Kallan MJ, Durbin DR, Winston FK. Effectiveness of child safety seats vs seat belts in reducing risk for death in children in passenger vehicle crashes. Arch Pediatr Adolesc Med 2006; 160:617-21.

8. Committee on Injury, Violence, and Poison Prevention, Durbin DR. Child passenger safety. Pediatrics 2011; 127:788-93.

9. Karkee R, Lee AH. Epidemiology of road traffic injuries in Nepal, 2001-2013: systematic review and secondary data analysis. BMJ Open 2016; 6:e010757.

10. Razzak JA, Khan UR, Zia N, Azam I. A child an hour: burden of injury deaths among children under 5 in Pakistan. Arch Dis Child 2013; 98:867-71.

11. Kulanthayan S, Razak A, Schenk E. Driver characteristics associated with child safety seat usage in Malaysia: a cross-sectional study. Accid Anal Prev 2010; 42:509-14

12. Singapore Statutes Online, Attorney-General's Chambers, Singapore. Road traffic act (Chapter 276). Available at: https://sso.agc.gov.sg/SL/RTA1961-S688-2011. Accessed December 20, 2018.

13. Chong SL, Tyebally A, Chew SY, et al. Road traffic injuries among children and adolescents in Singapore - who is at greatest risk? Accid Anal Prev 2017; 100:59-64

14. Chong SL, Chew SY, Feng JX, et al. A prospective surveillance of paediatric head injuries in Singapore: a dual-centre study. BMJ Open 2016; 6:e010618.

15. Sauber-Schatz EK, Thomas AM, Cook LJ; Centers for Disease Control and Prevention (CDC). Motor vehicle crashes, medical outcomes, and hospital charges among children aged 1-12 years - crash outcome data evaluation system, 11 states, 2005-2008. MMWR Surveill Summ 2015; 64:1-32.

16. Noor Faradila P, Baba M, Mohd Syazwan S, Azhar H, Mohd Rasid O. Drivers' knowledge and attitudes towards child restraint system (CRS) usage. Malaysian J Public Health Med 2018; (2):66-72.

17. Chen X, Yang J, Peek-Asa C, Li L. Parents' experience with child safety restraint in China. BMC Public Health 2014; 14:318.

18. Siddiqui E, Ejaz K, Waheed S, Kazi GI, Khursheed M. Attitudes towards child restraints and seat belts usage in the learned population of Karachi, Pakistan. World J Emerg Med 2014; 5:223-8.

19. Purc-Stephenson RJ, Ren J, Snowdon AW. An exploratory study of parents' use and knowledge of car safety seats in Beijing, China. Int J Inj Contr Saf Promot 2010; 17:231-8.

20. Yoon HS, Kim YD. Parental awareness and perception for correct use of child occupant restraints in Korea. Traffic Inj Prev 2010; 11:279-85.

21. Decina LE, Lococo KH, Ashburn W, Rose J. Identifying strategies to reduce the percentage of unrestrained young children. NHTSA Technical Report DOTHS811076. Washington DC: National Highway Transport Safety Administration, 2009 .

22. Garcês AQ, Coimbra IB, Silva DS. Transporting children in cars and the use of child safety restraint systems. Acta Ortop Bras 2016; 24:275-8.

23. Ma S, Tran N, Klyavin VE, et al. Seat belt and child seat use in Lipetskaya Oblast, Russia: frequencies, attitudes, and perceptions. Traffic Inj Prev 2012; 13 Suppl I:76-81.

24. Valent F, Barbone F. Automotive child restraint systems in northeastern Italy. Acta Paediatr 2003; 92:958-64.

25. Andijani S. Knowledge, attitude, and practice of parents regarding children's car safety seat. Int J Med Dev Countries 2017; 1:46-51.

26. Sevketoğlu E, Hatipoğlu S, Esin G, Oztora S. Knowledge and attitude of Turkish parents regarding car safety seats for children. Ulus Travma Acil Cerrahi Derg 2009; 15:482-6.

27. Ndu KI, Ekwochi U, Osuorah DC, et al. Parental practice of child car safety in Enugu, Southeast Nigeria. Pediatr Health Med Ther 2016; 7:141-8.

28. Naznin F, Currie G, Logan D. Exploring road design factors influencing tram road safety - Melbourne tram driver focus groups. Accid Anal Prev 2018; 110:52-61.

29. MacMillan K, Hewitt E. Qualitative research with young people: road safety. In: Transport Research Series, Scottish Government Social Research 2008. Available at: https://www.nls.uk/scotgov/2008/0075367.pdf. Accessed December 20, 2018.

30. Tong A, Sainsbury P, Craig J. Consolidated criteria for reporting qualitative research (COREQ): a 32-item checklist for interviews and focus groups. Int J Qual Health Care 2007; 19:349-57.

31. United Nations. World Economic Situation and Prospects 2016. Available at: http://www.un.org/en/development/desa/policy/wesp/wesp_current/2016wesp_ full_en.pdf. Accessed December 20, 2018.

32. Bilston LE, Finch C, Hatfield J, Brown J. Age-specific parental knowledge of restraint transitions influences appropriateness of child occupant restraint use. Inj Prev 2008; 14:159-63.

33. Zaza S, Sleet DA, Thompson RS, Sosin DM, Bolen JC; Task Force on Community Preventive Services. Reviews of evidence regarding interventions to increase use of child safety seats. Am J Prev Med 2001; 21(4 Suppl):31-47.

34. Ehiri JE, Ejere HO, Hazen AE, et al. Interventions to increase children's booster seat use: a review. Am J Prev Med 2006; 31:185-92.

35. Kedikoglou S, Belechri M, Dedoukou X, et al. A maternity hospital-based infant car-restraint loan scheme: public health and economic evaluation of an intervention for the reduction of road traffic injuries. Scand J Public Health $2005 ; 33: 42-9$. 


\section{APPENDIX}

Guiding questions for focus group interviews

\begin{tabular}{|c|c|}
\hline Domain & Specific questions for guidance \\
\hline $\begin{array}{l}\text { Knowledge of motor vehicle } \\
\text { collisions as a leading cause for } \\
\text { child death and injuries }\end{array}$ & $\begin{array}{l}\text { - What type of unintentional injury is the leading cause of death to toddlers, worldwide? } \\
\text { - Do you think the leading cause of death and injury to children is preventable? If so, why? If not, } \\
\text { - Why? } \\
\text { think so? } \\
\text { - What is the likelihood of a child in Singapore being involved in a motor vehicle collision? }\end{array}$ \\
\hline $\begin{array}{l}\text { Child car restraint and seat belt } \\
\text { usage among non-first-time parents }\end{array}$ & $\begin{array}{l}\text { - How old are the other children that you care for? What mode of transport do you use most of the } \\
\text { time? } \\
\text { - What type of child car restraints do they use? Which direction does it face - front facing or rear } \\
\text { facing? } \\
\text { Who (if anyone) taught you how to install the child car seat? } \\
\text { - How often do you use the child car restraint? For example, out of ten car trips, how many car trips } \\
\text { is the child buckled in the child car restraint? } \\
\text { child car seat? } \\
\text { - What do you do to overcome these difficulties? }\end{array}$ \\
\hline Perception of child car restraints & $\begin{array}{l}\text { - } \text { - What do you think is the purpose of the child car seat? } \\
\text { - How does the child car seat help your child in the event of a collision? } \\
\text { - What is the Singapore law on the use of child car seats? } \\
\text { - Why is it important to obtain, install and place the child in the correct child car seat? } \\
\text { - For what age group (and above) can the child be placed in a forward facing child seat? } \\
\text { - For what age group (and above) can the child be placed in a booster seat? } \\
\text { - For what age group (and above) would a seat belt be sufficient for a child? } \\
\text { - What are your thoughts about GrabFamily or Uber Car Seat option when booking for a ride? Would } \\
\text { - What choose it? Why or why not? } \\
\text { - Whe factors that contribute to or influence your decision to purchase and use the child } \\
\text { - What brands of car seats are reliable? How do you know if they are reliable? }\end{array}$ \\
\hline $\begin{array}{l}\text { Accessibility of information and } \\
\text { support systems }\end{array}$ & $\begin{array}{l}\text { - How do you obtain information on the correct type of child car seat? With regards to infant and } \\
\text { child care products like car seats and strollers, what sources of information influence your } \\
\text { decisions and choices? } \\
\text { - How do your friends/relatives influence your decisions on the use of car restraints? } \\
\text { - If you have difficulty installing your child car seat, whom will you ask? How confident are you that } \\
\text { they know the correct method of installation? }\end{array}$ \\
\hline Front-seat passenger & $\begin{array}{l}\text { - Does your child sit on the front passenger seat of a car or taxi? Why/why not? } \\
\text { - At what age group (and above) is it safe for a child to sit in the front seat? }\end{array}$ \\
\hline Others & $\begin{array}{l}\text { - Please share any thoughts or feedback you have that we have not discussed or that you feel the } \\
\text { need to share. } \\
\text { - What do you think should be done to increase public awareness on the importance of using } \\
\text { appropriate child car restraints? }\end{array}$ \\
\hline
\end{tabular}

